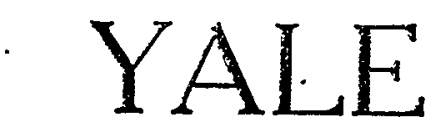

\title{
LAW
}

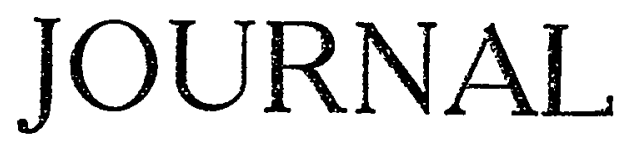

Vol. XXI.

NOVEMBER, 1911

No. 1

-

\section{NEW STATES AND CONSTITUTIONS}

An Address Before the Lai' School of Yale University, Monday, Inne 19, Igri, by George W. Wickersham, Attorney

General of the United States..

Current discussion in and out of Congress concerning the admission as States of the Territories of Arizona and New Mexico, has taken a wide range, and has involved much debate concerning the nature and effect of many of the provisions contained in the constitutions proposed by the new States respectively, not only as applicable to them, but as institutional features which may be applied to other communities.

That a frequent recurrence to fundamental principles is necessary to preserve the blessings of liberty and keep government free, is recognized and declared in the constitutions of more than one of the States. ${ }^{1}$

It is a fortunate circumstance, therefore, that the nature of these proposed constitutions should have been so prominently brought before the people as to provoke discussion, not only of their prorisions, but of the fundamental principles upon which our system of government is founded and maintained, and of the nature and effect upon them of the conceptions underlying the organization of one at least of these proposed new States, and

1 See, e. g., Constitution of Vermont, I777, Chap. I, par. XVI; Virginia Bill of Rights, 1776 , Sec. 15 ; New Hampshire Constitution of 1792 , Part I, Art. 38 ; Pennsylvania Constitution of 1776 , Declaration of Rights, Sec. XIV. 
which, to a certain extent, have been already adopted in some of the admitted States."

While a free, enterprising and progressive people will not reject improvements simply because they are new or untried, yet thoughtful Americans must ever consider any radical changes proposed in their government, state or national, in the light of Washington's warning to resist with care the spirit of innovation upon the principles of the institutions established by the Constitution of the United States, lest alterations in the forms of our fundamental structures of government "impair the energy of the system and undermine what cannot be directly overthrown."

The Constitution of the United States established a union of thirteen States, each of which had been separately organized under a government republican in form; that is to say, a government in which it was recognized that the ultimate sovereignty resided in the adult male people-with some exceptions, differing in different States, dependent upon color, race, condition of servitude, or property qualifications. This sovereignty was exercised by means of a general scheme of government under which (I) a constitution or fundamental law was formulated by delegates chosen from among the qualified voters, in some cases empowered to ordain and establish the constitution as binding upon all the people, and in others merely to submit it, when formulated, for popular approval, under conditions making the same binding upon all, if affirmatively approved by the votes of a specified percentage of the qualified male voters; and

(2) Within the limitations prescribed in such constitutions, laws were made by representatives periodically chosen for such purpose, generally distributed between two legislative bodies having different tenures and qualifications; were executed by governors and other executive officials chosen for limited periods by popular vote, or appointed by those so chosen; and the laws were interpreted and applied by judges, generally appointed to hold office during. good behavior, but subject to removal on joint address of both branches of the legislature, or in proceedings for impeachment.

Differing in many details, the governments of all the thirteen States in their general outlines were conformable to the foregoing description, and were all denominated republican.

"Constitution of Michigan, I909. Art. XVII. Constitution of Oklahoma, Art. V. Oregon, Laws of 1903, p. 24 . 
The Constitution provided in Section 3 of Article IV:

"New States may be admitted by the Congress into this Union; but no new States shall be formed or erected within the jurisdiction of any other State; nor any State be formed by the junction of two or more States, or parts of States, without the consent of the Legislatures of the States concerned, as well as of the Congress."

By Section +:

"The United States shall guarantee to every State in this Union a republican form of government, and shall protect each of them against invasion; and on application of the Legislature, or of the Executive (when the Legislature cannot be convened), against domestic violence."

The general purpose of the provisions in Section + was indicated in the debate over them in the Constitutional Convention. Mr. Randolph said they had two objects: (I) to secure Republican Government, (2) to suppress domestic commotions. He urged the necessity of both these provisions. Mr. Madison moved to sulbstitute "that the Constitutional authority of the States shall be guarantied to them respectively agst. domestic as well as foreign violence." But other delegates objected to this as perpetuating the existing constitutions of the States, some of which Mr. Houston thought were very bad and ought to be revised and amended. In reply to a suggestion that the States should be left to suppress their own rebellions, Mr. Gorham thought it would be very strange were a rebellion to exist and the general government restrained from subduing it. "At this rate," he said, "an enterprising Citizen might erect the standard of Monarchy in a particular State, might gather together partizans from all quarters, might extend his views from State to State, and threaten to establish a tyranny over the whole, \& the Genl. Govt. be compelled to remain an inactive witness of its own destruction. With regard to different parties in a State," he humorously added, "as long as they confine their disputes to words they will be harmless to the Genl. Govt. \& to each other." 3

Chief Justice Taney, in delivering the opinion in Luther i. Borden, ${ }^{*}$ said that under the above quoted provision of the Constitution:

\footnotetext{
${ }^{3}$ Records of the Federal Convention, Farrand, Vol. II, p. f\&.

${ }^{7}$ Howard, I-q2.
} 
- "It rests with Congress to decide what government is the established one in a State. For as the United States guarantee to each State a republican government, Congress must necessarily decide what government is established in the State before it can determine whether it is republican or not. And when the senators and representatives of a State are admitted into the councils of the Union, the authority of the government under which they are appointed, as well as its republican character, is recognized by the proper constitutional authority. And its decision is binding on every other department of the government, and could not be questioned in a judicial tribunal."

"The guaranty," said Chief Justice Waite, in a later case," "is of a republican form of government. No particular government is designated as republican, neither is the exact form to be guaranteed, in any manner especially designated. Here, as in other parts of the instrument, we are compelled to resort elsewhere to ascertain what was intended.

"The guaranty necessarily implies a duty on the part of the States themselves to provide such a government. All the States had governments when the Constitution was adopted. In all the people participated to some extent, through their representatives, elected in the manner specially provided. These governments the Constitution did not change. 'They were accepted precisely as they were, and it is, therefore, to be presumed that they were such as it was the duty of the States to provide. Thus

-we have unmistakable evidence of what was republican in form, within the meaning of that term as employed in the Constitution."

The general scheme of government running through the constitutions of all the eleven States which had adopted constitutions at the time of the adoption of the Federal constitution, the salient outlines of which have been indicated, and even that embodied in or established under the charters of Connecticut and Rhode Island, constituted the American system of republican government which Chief Justice Fuller in $I n R e$ Duncan ${ }^{\circ}$ said was that whose distinguishing feature "is the right of the people to choose their own officers for governmental administration and pass their own laws in virtue of the legislative power reposed in representative bodies, whose legitimate acts may be said to be those of the people themselves."

5 Minor : Happersett: 21 Wall., 162, x75.

" 139 UT. S.. $449,46 \mathrm{~T}$. 
The nature of the governments established in the States is therefore a matter of necessary concern to Congress, for it must guarantee to each State a republican form of government, and as the National government must also protect every State against domestic violence, common prudence requires a careful scrutiny of the qualifications of a new applicant for admission to the family of States, in order to determine whether or not its electorate is properly qualified to maintain stable and peaceable conditions under the particular form of republican government which it proposes to adopt.

The Council of Safety, meeting at Halifax, North Carolina, on August 9, 1776, recommended to the people of that "now Independent State," the election of delegates to represent them in Congress, and that the greatest attention be paid to such election, particularly in view of this important consideration:

"That it will be the Business of the Delegates then Chosen not only to make Laws for the good government of, but also to form a constitution for, this State; that this last, as it is the Corner Stone of all Law, so it ought to be fixed and Permanent, and that according as it is well or ill Ordered, it must tend in the first degree to promote the happiness or Misery of the State." $T$

Among the principles which the political experience and theories of the colonists had supplied was "the idea of a constitution superior to legislative enactments, and of certain natural rights secured by such a constitution." s

"Unquestionably," says Professor George Elliott Howard in his introduction to Judge Lobingier's interesting work entitled "The Peoples Law, or Popular Participation in Law-Making,""Unquestionably the American people have made three great contributions to the political organism and to political science: the constitutional convention, the written constitution and constitutional law" (p. XI). He further points out that while each of these institutions has an earlier history more or less distinct, yet that "as a distinct political organ, with a special function to perform-an organ to be compared to a court, an executive, or a legislature-the constitutional convention was born and developed in America. As a representative body, created according to definite principles to discharge a single special function, that of enacting organic as opposed to mere statute law, it first made

TLobingier, The Peoples Law, p. 152.

s Dodd, The Revision and Amendment of State Constitutions, p. 2. 
its appearance, fully differentiated, in the Massachusetts convention of 1780 (the type of subsequent state constitutional conventions) and in the national convention of 1787 . Since then it has gained its own law and its own literature, and it has taken its proper place in the Staatsrecht of the world." In like manner, he says, while in English and Colonial history there weré forerunners of constitutions, "Nevertheless, the written constitution as an actuality, as a recognized and permanent form of organic law, is essentially the product of American political evolution" (id., p. XII).

Hence, Professor Stimson says:

"The Constitution is the permanent will of the people; a law is but the temporary act of their representatives, who have only such power as the people choose to give them."

It was in the light of these principles that the constitution of Massachusetts was framed in I780-that constitution which has been described as "the most perfect expression of the American theory as understood at the close of the Revolution," and which has not only remained as the fundamental law of the great Commonwealth of Massachusetts to this day, but which has also served as a model for many others. It has called forth the highest encomiums from even the advocates of latter-day Democracy ${ }^{10}$ and must ever remain a monument to the patriotism, sagacity and statesmanship of the illustrious men who framed it.

With even greater patience, skill and foresight the delegates to the National Convention of 1787 wrought out a Constitution for the union of States. They sought to construct a fundamental law for the Union with the same view to permanence and stability as that with which the Massachusetts constitution was framed; in order to secure the blessings of liberty and good government, not only to themselves, but to their posterity. Justice Story said of it:

"The constitution unavoidably deals in general language. It did not suit the purposes of the people, in framing this great charter of our liberties, to provide for minute specifications of its powers, or to declare the means by which those powers should be carried into execution. It was foreseen that this would be a perilous and difficult, if not an impracticable, task. The instrument was not intended to provide merely for the exigencies of a

9 "The American Constitution," p. 7.

${ }^{10}$ See Lobingier, pp. $17 \mathrm{I}$, I77-9. 
few years, but was to endure through a long lapse of ages, the events of which were locked up in the inscrutable purposes of Providence. It could not be foreseen, what new changes and modifications of power might be indispensable to effectuate the general objects of the charter; and restrictions and specifications, which, at the present, might seem salutary, might, in the end, prove the overthrow of the system itself. Hence, its powers are expressed in general terms, leaving to the legislature, from time to time, to adopt its own means to effectuate legitimate objects, and to mould and model the exercise of its powers, as its own wisdom, and the public interests should require." 11

In providing in the Constitution for the admission of new States, it was specified that they might be admitted as States "into this Cnion." There was to be no discrimination between them and the original thirteen States. This was the deliberate conclusion of the Convention. Various propositions looking to a different result were submitted.": Gouverneur Morris suggested that "the rule of representation ought to be so fixed as to secure to the Atlantic States a prevalence in the national councils." Elbridge Gerry expressed a like view. ${ }^{13}$ It was proposed by another to apportion representation among the States "upon the principles of their wealth and number of inhabitants." But the contrary view prevailed.

What Congress understood this Constitutional provision to mean was shown when Vermont and Kentucky, the first two States to be admitted were, by acts of Congress passed respectively March 4 , I79I, and June I, 1792, each, "received and admitted into this Union as a new and entire member of the Lnited States of America." Tennessee was admitted in 1796 as "one of the United States of America," "on an equal footing with the original States in all respects whatsoever," and substantially the same language was employed with respect to all the States subsequently admitted.

It is the almost universal judgment of our people that the convention decided wisely in providing for the admission of States without discrimination between the original and the later ones, but it is interesting to note in passing that the fundamental laws for the creation of the three other great federations of English speaking states-those of British North America, Aus-

11 Martin i'. Hunter. I Wheat., 304-26.

1: Elliott's Debates, Vol. 5, pp. 155-6, 128, 228.

${ }^{13}$ Eliott's Debates, Vol. 5, pp. 279. 310. 
tralasia and South Africa-all contain provisions authorizing the federal parliament to admit new states upon such conditions as it may deem expedient to impose, and to discriminate as between the original members of the Union and those subsequently admitted. ${ }^{14}$

No uniformity of procedure to be observed in the admission of States was established by the Constitution, nor has resulted from common practice. A constitution was adopted by the legislature of Vermont in March, 1787 , which, after reciting that "it is absolutely necessary, for the welfare and safety of the inhabitants of this State, that it should be henceforth a free and independent State, and that a just, permanent, and proper form of government should exist in it, derived from and founded on the authority of the people only, agreeable to the direction of the honorable American Congress," declared that:-

"We, the Representatives of the freemen of Vermont, in General Convention met, $* * *$ do, by virtue of authority vested in us by our constituents, ordain, declare and establish the following Declaration of Rights and Frame of Government, to be the Constitution of this Commonwealth, and to remain in force therein forever unaltered, except in such articles as shall hereafter on experience be found to require improvement, and which shall, by the same authority of the people, fairly delegated, as this Frame of Government directs, be amended or improved, for the more effectual obtaining and securing the great end and design of all government hereinbefore mentioned." 15

14 Commonwealth of Australia Constitution Act, July 9, rgoo, Chapt. VI:-

"I2I. The Parliament may admit to the Commonwealth or establish new States, and may upon such admission or establishment make or impose such terms and conditions, including the extent of representation in either House of Parliament, as it thinks fit."

"Modern Constitutions," by W. F. Dodd, Vol. I, p. 65. "The Constitution of Australia," by W. H. Moore, Melbourne, rgro.

The British North America Act (March 29, I867), Section 146-

**** on such terms and conditions in each case as are in the addresses expressed and as the queen thinks fit to approve, subject to the provisions of this act."

The British North America Act, I87I. The British North America Act, 1886. "Modern Constitutions," pp. 220, 221, 224.

South Africa Act, I909, Secs. I49-150:-“on such terms and conditions as to representation and otherwise in each case as are expressed in the addresses and approved by the King ***." Brand, "The Cinion of South Africa," Oxford, rgog.

15 Thorpe's American Charters, etc., Vol. 6, p. 375r. 
The Act of Congress approved February I8, I791, merely recites that the State of Vermont has petitioned Congress "to be admitted a member of the United States," and enacts that on March fourth, I79r, the said State "be received and admitted into this Union as a new and entire member of the United States of America."

The act admitting Kentucky into the Union, passed February 4, I79I, ${ }^{16}$ recited that the Commonwealth of Virginia had consented that the District of Kentucky, within its jurisdiction, should be formed into a new State, and that a convention of delegates, chosen by the people of the district, had petitioned Congress to consent, and it was thereupon enacted that the said district be formed into a new State, separate from and independent of Virginia, and be received and admitted into the Union "as a new and entire member of the United States of America."

The act of June $1, x 796$, declared that:-

"The whole of the territory ceded to the United States by the State of North Carolina shall be one State, and the same is hereby declared to be one of the United States of America, on an equal footing with the original States in all respects whatever, by the name and title of the State of Tennessee." ${ }^{17}$

A constitution had been adopted for that State in February, 1796, but no reference to it is contained in the act admitting the State into the Union.

The first enabling act of Congress, or act specifically authorizing the inhabitants of a portion of territory to form for themselves a constitution and state government upon which to be admitted into the Union, was that providing for the admission of the State of Ohio, approved April 30, I802. ${ }^{18}$ It authorized:

"All male citizens of the United States, who shall have arrived at full age, and resided within the said territory at least one year previous to the day of election, and shall have paid a territorial or county tax, and all persons having in other respects the legal qualifications to vote for representatives in the general assembly of the territory,"

to choose representatives to form a convention, to first determine by a majority of the whole number elected whether it be

\footnotetext{
${ }^{20}$ Poore, Charters and Constitutions, Vol. I, p. 647.

17 Poore, Charters and Constitutions, Vol. II, p. $x 676$.

18 Poore, Charters and Constitutions, Vol. II, p. 1453
} 
expedient to form a constitution and state government, and if so, by ordinance to provide for electing representatives to form a constitution or frame of government, "provided the same shall be republican and not repugnant to" the ordinance for the government of the northwestern territory. The convention so authorized met and framed a constitution which was not submitted to the people, ${ }^{19}$ but Congress, by act approved February 19, I803, declared that the State of Ohio had become one of the United States of America. ${ }^{20}$

The first effort to bind a new State to terms and conditions other than those to which it would be subject in like manner as all other States under and by force of the provisions in the Constitution of the United States was expressed in the Enabling Act for Louisiana, passed February 20 , ISII. ${ }^{21}$

That act authorized "all free white male citizens of the United States, who shall have arrived at the age of twenty-one years, and resided within" the territory described in the act, "at least one year previous to the day of election, and shall have paid a territorial, county, district or parish tax: and all persons having in other respects the legal qualifications to vote for representatives in the general assembly of the said territory," to choose representatives to form a convention to frame a constitution and state government for the people within the territory, and by section 3 that if it be determined to be expedient so to do, then the Convention might "in like manner declare, in behalf of the people of the said territory, that it adopts the constitution of the Lnited States; whereupon the said convention shall be, and hereby is, authorized to form a constitution and state government. for the people of the said territory: Prozided, the constitution to be formed, in virtue of the authority herein given, shall be republican, and

19 Poore, Charters and Constitutions, Vol. II, p. 1455.

20 Poore, Charters and Constitutions. Vol. II, p. 1464 .

The ordinance of 1787 for the government of the Northwestern Territory provided in Article $\mathrm{V}$ for the formation of states and their admission into the Union, and that whenever any of said states should have sixty thousand free inhabitants therein, they should be at liberty to form a permanent constitution and state government. "Provided, the Constitution and government so to be formed shall be republican, and in conformity to the principles contained in these articles $* * *$."

212 Stat., 64 r. 
consistent with the constitution of the United States: that it shall contain the fundamental principles of civil and religious liberty ;:2 $* * *$ " besides certain other specified provisions.

It was further provided that if such constitution should be adopted by the State, it should be transmitted to Congress, and if it were not disapproved by Congress at its next session after receipt thereof, the said State should be admitted into the Union upon the same footing with the original States. A constitution was adopted by the convention in conformity with the provisions of the Enabling Act, and, on April 8, I8I2, Congress passed an act reciting compliance with the previous requirements, and declaring that the said State was admitted into the Lnion, "on an equal footing with the original states, in all respects whatever, by name and title of the State of Louisiana: Provided, That it shall be taken as a condition upon which the said state is incorporated in the Union, that * * * all *** conditions and terms contained in the third section of the act, the title whereof is hereinbefore recited, shall be considered, deemed and taken, fundamental conditions and terms, upon which the said state is incorporated in the Union." 23

In the case of Permoli ${ }^{\prime}$. First Municipality ${ }^{2+}$ it was sought to have it adjudged that an ordinance of the First Municipality of the City of New Orleans prohibiting the carrying to or exposing in any of the Catholic churches of that Municipality any corpse, or the celebration by any priest of a funeral at such churches, and requiring all funeral rites to be performed in a designated obituary chapel was void, as being in violation of the provisions of the above mentioned Enabling Act as well as of the act admitting the State into the Union upon condition that its constitution should contain the fundamental principles of civil and religious liberty. But the court pointed out that the Constitution of the United States makes no provision for protecting the citizens of the respective States in their religious liberties, leaving that subject entirely to the State constitutions and laws; that all that Congress intended by the Enabling Acts was to declare, in advance, to the people of the territories, the basic principles their constitutions should contain:

"*** this was every way proper under the circumstances," said Mr. Justice Catron: "the instrument having been

\footnotetext{
22,2 Stats. at L., 642.

${ }^{23} 2$ Stats. at L., 703.

${ }^{21} 3$ Howard, 588.
} 
duly formed and presented, it was for the national legislature to judge whether it contained the proper principles, and to accept it if it did, or reject it if it did not. Having accepted the constitution and admitted the state, 'on an equal footing with the original states in all respects whatever,' in express terms, by the act of 1812 , Congress was concluded from assuming that the instructions contained in the act of I8I I had not been complied with. No fundamental principles could be added by way of amendment, as this would have been making part of the state constitution; if Congress could make it in part, it might, in the form of amendment, make it entire. The conditions and terms referred to in the act of I8I2, could only relate to the stipulations contained in the second proviso of the act of ISII involving rights of property and navigation; and in our opinion were not otherwise intended" (pp. 6o9-10).

A similar question arose in the case of Pollard's Lessee $v$. Hagan, ${ }^{25}$ where it was held that a declaration contained in the compact entered into between the United States and Alabama, when the latter State was admitted into the Union, as a condition to her admission, would be void if inconsistent with the Constitution of the United States.

It was pointed out by the court that all constitutional laws are binding on the people in the new States and the old ones, whether they consent to be bound by them or not.

"Every constitutional act of Congress," said Mr. Justice McKinley, "is passed by the will of the people of the United States, expressed through their representatives, on the subject-matter of the enactment; and when so passed it becones the supreme law of the land, and operates by its own force on the subjectmatter in whatever state or territory it may happen to be." (p. 224.)

Notwithstanding these decisions, rendered in $I S_{45}$, and the very clear provisions of the Constitution, Congress has proceeded in many subsequent acts for the admission of new States to prescribe terms and conditions purporting to bind the new State, and which it required the new State to accept by ordinance expressed to be "irrevocable without the consent of the people of the State and of the United States." Such conditions were imposed with respect to Missouri in $182 \mathrm{I}$ (3 Stat., 645), Nebraska in I864 ( 3 Stat., 47), Colorado in I875 (IS Stat., 474), North Dakota, South Dakota, Nontana and Washington in 1889 (25 Stat., 676), Utah in 1894 (28 Stat., x07), and Oklahoma in Ig06 (34 Stat., 267).

\footnotetext{
2ri 3 How., 212.
} 
The Enabling Act of the State of Oklahoma, passed June 16 , 1906 ( 34 Stat., 267), provided that the constitution to be adopted for the new State "shall be republican in form, and make no distinction in civil or political rights on account of race or color, and shall not be repugnant to the Constitution of the United States and the principles of the Declaration of Independence."

The capitol of the State, it was enacled, shall be temporarily at Guthrie, and shall not be changed therefrom previous to $\mathrm{rgr} 3$, but shall after that year be located by the electors of said State at an election to be provided for by the legislature.

The act further required the convention to provide in the Constitution so to be adopted;

"First. That perfect toleration of religious sentiment shall be secured, and that no inhabitant of said State shall ever be molested in person or property on account of his or her mode of religious worship, and that polygamous or plural marriages are forever prohibited.

"Second. That the manufacture, sale, barter, giving away, or otherwise furnishing $* * *$ intoxicating liquors within those parts of said State, now known as the Indian Territory and the Osage Indian Reservation, and within any other parts of said State which existed as Indian reservations $* * *$ shall be prohibited.

$$
* \quad * \quad * \quad * \quad * \quad * * *
$$

"Sixth. That said State shall never enact any law restricting or abridging the right of suffrage on account of race, color, or previous condition of servitude." and finally,

"That the constitutional convention provided for herein shall, by ordinance irrevocable, accept the terms and conditions of this Act."

The Convention was held, a constitution and an "ordinance irrevocable" adopted, and thereupon Oklahoma was admitted to the Union by proclamation of President Roosevelt November 16, I907.. Three years later, on December 29, I9I0, its legislature passed an act providing for the removal of the capitol from Guthrie to Oklahoma City notwithstanding its covenant with the United States not to so remove prior to I9r3. Whatever might be said of the ethics of this act, the Supreme Court of the United States in the very recent case of Coyle $v$. Smith, decided May 29, I9II, held that the power to locate its own seat of government and to determine when and how it should be changed from one place 
to another was essentially and peculiarly a state power, which was acquired by Oklahoma when it was admitted into the Union on an equality with the other States, and that Congress might not, as a condition to the admission of a new State, constitutionally restrict its authority or impose upon it any limitations not common to the other States of the Union. "It may well happen," said Mr. Justice Lurton, in delivering the opinion of the court, "that Congress should embrace in an enactment introducing" a new State into the Union legislation intended as a regulation of commerce among the States or with Indian tribes situated within the limits of such new State, or regulations touching the sole care and disposition of the public lands or reservations therein, which might be upheld as legislation within the sphere of the plain power of Congress. But, in every such case such legislation would derive its force not from any agreement or compact with the proposed new State, nor by reason of its acceptance of such enactment as a term of admission, but solely because the power of Congress extended to the subject, and, therefore, would not operate to restrict the State's legislative power in respect of any matter which was not plainly within the regulating power of Congress."

An interesting variation from the rules observed with respect to the admission of all other States is furnished by the case of the State of Utah. It is familiar history that the especial problem with which the national government had to grapple during the territorial days of Utah was the institution of polygamy or plural marriages, a problem which led to the drastic legislation of Congress repealing the charter of the "Church of Jesus Christ of Latter Day Saints," commonly known as the Mormon Church, the appointment of a receiver of its property and the application of it on principles of $c y$ près, - all of which were sustained by the Supreme Court of the United States in the case of Mormon Church v. United States. ${ }^{20}$ When, therefore, Congress came to deal with the establishment of a government for Utah upon its admission as a State into the Union, it provided for the formation of a constitution and state government for the proposed State which should be "republican in form and make no distinction in civil or political rights on account of race or color, except as to Indians not taxed, and not to be repugnant to the

${ }^{26} 136$ U. S., I. 
Constitution of the United States and the principles of the Declaration of Independence." The Enabling Act further required the constitutional convention to provide by ordinance, irrevocable without the consent of the United States and the people of said State, among other things;

"That perfect toleration of religious sentiment shall be secured and that no inhabitant of said State shall ever be molested in person or property on account of his or her mode of religious worship: Provided, That polygamous or plural marriages are forever prohibited."

The constitutional convention thereupon framed, and the people adopted a Constitution, which contained in itself, as Article 3 thereof, the above-mentioned required provisions, and declared that such provisions "shall be irrevocable without the consent of the United States and the people of this State." Nevertheless, by the twenty-third article of the Constitution, provision was made for the adoption of any amendment to the Constitution without exception, by the vote of two-thirds of the members of each house of the legislature, and of a majority of the electors of the State voting thereon. So that this so-called irrevocable ordinance thus stipulated in one part of the Constitution to be beyond change without the consent of the United States and the people of the State, under the subsequent articles may be modified or repealed at any time by the vote of a majority of each house of the legislature of the State, confirmed by that of a majority of the qualified electors voting thereon. Perfect toleration of religious sentiment and the prohibition of polygamous or plural marriages sought to be accomplished by Congress, therefore rest for their continuance, not upon any binding compact between the State and the general Government, but solely upon the continued willingness of a majority of the qualified electors of the State to retain such provisions as a part of its fundamental law.

It is well to keep clearly in mind the precise conditions under which new States are admitted into the Union, and the powers and privileges which they will possess after such admission, in determining whether or not a particular applicant shall be received into full fellowship in the nation.

Prior to the admission of the State of Oklahoma no radical departure in the general scheme of State government from the recognized common standard was proposed by the constitution of any new State. Every one of them, judged by the principles 
above referred to, and tested by the general schemes embodied in the constitutions of the original States, could be fairly said to be republican in character, and to contain nothing inconsistent with the principles of the Federal Constitution. Everyone presented a government which in general conformed to the type which has become recognized as the American representative republican form of government.

The Constitution of Oklahoma presented new considerations and was the occasion of much discussion and considerable hesitation over its approval.

The special census of Oklahoma and Indian Territory which were combined into the State of Oklahoma, taken as of July $\mathrm{I}$, I897, showed a total population of $1,414,042$. Of this number 334,035 were white males upwards of twenty-one years of age. The vote on the adoption of the Constitution was, for its adoption, I80,333; against it, 75,059; total, 253,392. The total vote was therefore upwards of seventy-five per cent. of the entire number of adult white males, and the total vote on the Constitution was nearly nineteen per cent. of the entire population. It obviously met with the approval of the general body of the people of the State. By proclamation dated November 16, 1907, President Roosevelt declared that:

"The said constitution and government of the proposed State of Ollahoma are republican in form, and that the said constitution makes no distinction in civil or political rights on account of race or color and is not repugnant to the Constitution of the United States or to the principles of the Declaration of Independence, and that it contains all of the six provisions expressly required by Section 3 of the said act to be therein continued," $* \quad * \quad *$

and declared it to be admitted as a State into the Union.

Mr. Bryce in "The American Commonwealth," notes that the chief of the tendencies revealed by the Constitutions of the last forty years is for the Constitutions to grow longer. This, he says, is an absolutely universal rule. ${ }^{2 s}$ Woodrow Wilson says in his work, "The State": "The danger is that constitution making will become with us only a cumbrous mode of legislation." ${ }^{29}$ In the Constitution of Oklahoma it has become so. That Constitution

27 35 Stat., Part 2, p. 216r.

as Vol. I, p. 454 (3rd ed.).

2n Ed. of I899, p. 475 . 
is of inordinate length. It is divided into 24 articles and 312 sections, and it fills 70 closely printed octavo pages. A large part of its provisions are of matters which may be the proper stbjects of legislation, but which have no place in the fundamental law, tested by established American standards. While providing for a bicameral legislature, it reserves to the people powers of initiative and referendum respecting legislation. Eight per cent. of the number of qualified voters are given the right to propose laws, and fifteen per cent. amendments to the Constitution. The referendum of any law passed by the legislature may be ordered by petition signed by five per cent. of the qualified voters. Percentages are to be based on the total number of votes cast at the last preceding general election for the state officer receiving the highest number of rotes cast at such election. A measure rejected on referendum can not again be proposed within three years, except on petition of to'enty-five per cent. of the qualified roters. The Constitution may be amended in any particular, if agreed to by a majority of the members elected to each house, and then voted for by a majority of all the electors voting upon the proposition. But it is provided that no convention shall be called by the legislature to propose alterations, revisions or amendments to the Constitution, or to propose a new Constitution, unless the law for it be first approved by the people, on a referendum vote. The question of such proposed convention must be submitted to the people at least once in twenty years. These provisions, however, are not to impair the right of the people to amend by vote on an initiative proposition.

The Ollahoma Enabling Act also provided for submitting to the people of the territories of Arizona and New Mexico the question whether or not they should become one State and, if so, then for a convention to frame a Constitution for such state and to provide for its admission into the Union. A vote was had on this proposition and the decision was in the negative.

Subsequently, on June 20 , x910, an act was passed providing for the admission of the Territories as separate States. ${ }^{30}$ This act anthorized the election of delegates in each Territory to a convention empowered to form a Constitution and provide a government for the proposed State, which Constitution "shall be republican in form and make no distinction in civil or political

3" 36 Stats., 557. 
rights on account of race or color, and shall not be repugnant to the Constitution of the United States and the principles of the Declaration of Independence."

The convention was further required to provide "by an ordinance irrevocable without the consent of the United States and the people of said State-" a number of provisions. The Constitution, when formed, was to be submitted for the approval of the qualified voters of the territory at a convention to be held to consider the same, and "when said constitution and such provisions thereof as have been separately submitted shall have been duly ratified by the people of New Mexico as aforesaid a certified copy of the same shall be submitted to the President of the United States and to Congress for approval, together with a statement of the votes cast thereon and upon any provisions thereof which were separately submitted to and roted upon by the people. And if Congress and the President approve said constitution and the said separate provisions thereof, or, if the President approves the same and Congress fails to disapprove the same during the next regular session thereof, then and in that event the President shall certify said facts to the Governor of New Mexico, who shall, within thirty days after the receipt of said notification from the President of the United States, issue his proclamation for the election of the state and county offcers," etc. The same provision was made as to Arizona.

When the result of the election should be certified to the President, he was required immediately to issue his proclamation announcing the result of said election so ascertained.

"And upon the issuance of said proclamation by the President of the United States, the proposed State of New Mexico shall be deemed admitted by Congress into the Union, by virtue of this Act, on an equal footing with the other States," ${ }^{31}$ and in like manner as to Arizona.

There has been some discussion as to the precise function of the President under these provisions, and the critcria governing his action in approving or disapproving the constitution to be submitted pursuant thereto. It is quite clear that Congress may not delegate to the President its power to determine whether or not a State shall be admitted into the Union. The power conferred by Article 4, Section 4 of the Constitution is "New States may be admitted by the Congress into this Union." But that Con-

${ }^{31} 36$ Stat., 56r. 
gress may exercise a legislative power to take effect upon the ascertainment by the President of a specified fact, is well established. In such case the President is not exercising a delegated legislative power, but is the mere agent of the law-making department to ascertain and declare the event upon which its expressed will is to take effect." While therefore Congress may not empower the President to admit a territory as a State whenever it shall present to him a constitution which meets with his individual approval, it may provide for the admission of a State whenever it shall adopt a constitution which shall be republican in form and make no distinction in civil or political rights on account of race or color, and shall not be repugnant to the Constitution of the United States and the principles of the Declaration of Independence; and empower the President to ascertain and determine whether a particular constitution meets that description. If, therefore, the President should act pursuant to the provisions of the above-mentioned act, it would be presumably upon the ascertainment that the constitution presented met the requirements specified by Congress; no other consideration being submitted for his determination. But Congress is not - bound to approve the constitution and admit a State, even though it do conform with the conditions specified in the Enabling Act. Congress may, because of the general nature of the institutions provided in the proposed Constitution; because of the conditions under which the Constitution was adopted; because of the character or number of the electorate upon whose vote it was adopted; or because of any other reason which it may deem sufficient, or without any reason, reject a proposed Constitution in toto, or require it to be modified in any given particular as a condition to admitting the State.

To be sure, except in so far as it might conflict with some provision of the Federal Constitution, the new State might immediately after its admission into the Union, amend its Constitution or adopt a new one, and Congress would be powerless to. prevent. Its only protection against such an act would be to require it to employ provisions so regulating the means of amendment as to ensure against hasty or ill-considered changes. Thus, e. g., it might require the Constitution to provide that it should

32 See Field v. Clark, $x_{43}$ U. S., 649, 692; Butfield v. Stranahan, x92 U. S., 470,476 . 
only be amended with the consent of at least a majority of all the qualified voters of the State.

The Constitution of New Mexico was adopted by the Convention and submitted to the people of that Territory. The returns of the thirteenth census gave New Mexico, in 1910, a total population of 327,301 , of which 76,233 were native-born males over twenty-one years of age, and 4,269 naturalized foreign-born males over twenty-one years of age, making an apparent total voting population of 80,502 . There were cast, for the Constitution, $3 \mathrm{I}, 742$ votes; against it 13,399 votes, or a total of $45,14 \mathrm{I}$ on the question of its adoption-being about fifty-six per cent. of the total number of the qualified voters, and slightly less than fourteen per cent. of the total poptuation.

The Constitution so adopted, while exhibiting the tendency to undue length and minuiae above noted, yet compares favorably in that respect with the Constitution of Oklahoma. It contains twenty-two articles divided into 257 sections, and fills 38 ordinary printed octavo pages.

Legislative power is rested in a legislature divided into two chambers and there is a provision reserving to the people the power to disapprove, suspend and annul any law enacted by the legislature except appropriation and health laws, \&c.

This right must be exercised by petition signed by not less than ten per cent. of the qualificd electors in each of threefourths of the counties, and in the aggregate by not less than ten per cent. of the qualified electors of the State as shown by the total number of votes cast at the last preceding general election. The question of the approval or rejection of such laws must be submitted to the electorate at the next general election; and if a majority of the legal votes cast thereon. and not less than forty per cent. of the total number of such votes at such general election be cast for the rejection of such law, it shall be annulled and thereby repealed with the same effect as if the legislature had then repealed it. If such petitions be signed by not less than twenty-five per cent. of the qualified electors under each of the foregoing conditions, and filed with the secretary of state within ninety days after the adjournment of the session of the legislature at which the law was enacted, the operation of the law shall be thereby suspended and the question of its approval or rejection shall be likewise stbmitted to a general vote at the next. 
ensuing general election. If a majority of the votes cast thereon, and not less than forty per cent. of the total number of votes cast at such general election be cast for the rejection of such law, it shall be thereby annulled; otherwise it shall go into effect. In the matter of amending the Constitution, there is a marked reaction towards earlier standards. The framers of this proposed Constitution evidently propose that any changes in it shall be supported by an active public demand. They have therefore provided that the constitution may be amended by the vote of twothirds of all members elected to each of the two houses of the legislature, voting separately, and submitted to the electors of the State for their approval or rejection. But the proposal must be ratified by a majority of the electors voting thereon and by an affirmative vote equal to at least forty per cent. of all the votes cast at said election in the State in at least one-half of the counties thereof. In that event, and not otherwise, such amendment shall become a part of the constitution. Not more than three amendments may be submitted at one election, and if two or more amendments are proposed they shall be so submitted as to enable the electors to vote on each of them separately. Provision is also made for a constitutional convention to revise or amend the constitution at any time within twenty-five years by three-fourths vote of the members elected to each house; after twenty-five years, by two-thirds votes of the members of each house, who shall then submit the question of calling a convention to the electors at the next general election; and if a majority of the electors roting at such election in the State and in at least one-half of the counties thereof, shall vote in favor of calling a convention, the legislature shall at the next session provicle by law for calling the same. The compact with the United States required by the Enabling Act is embodied in the twenty-first article of the constitution, which is declared to be irrevocable without consent of the Linited States and the people of the State; and that no change or abrogation of its provisions in whole or in part shall be made by any constitutional amendment with the consent of Congress.

This Constitution has receired the formal approval of the President and is now before the Congress.

In very marked contrast with the constitution of New Mexico, both as to the number of votes cast for its adoption, the per- 
centage of the whole population roting with respect to it and the provisions of the constitution itself, is the constitution of Arizona, which was adopted by the people of that Territory on February 9, IgIr. The returns of the Thirteenth Census give Arizona in Igro a total population of 204,354 , of which $155,55^{\circ}$ are native born, and 48,804 foreign born. Of this population,

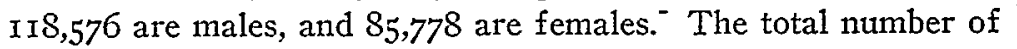
white males over twenty-one years of age is- $65, \mathrm{I} 33$, of which number 39,427 are native born and 5,896 naturalized citizens, so that the total voting population is, apparently, 45,323. There were cast for the Constitution 12,187 rotes, against it 3,822 votes, or a total of 16,009 on the question of its adoption, being about thirty-five per cent. of the total number of qualified voters, and slightly less than eight per cent. of the total population. The vote for the constitution was by less than twenty-seven per cent. of the voting population, and about six per cent. of the total population.

Congress may well consider whether or not a Territory in which only thirty-five per cent. of the qualified electors exhibit sufficient interest to vote upon the adoption of the fundamental law on which it seeks admission to the Union, gives evidence of that capacity for self-government which is so essential to the maintenance of free institutions.

The constitution thus adopted by the vote of this small percentage of the people of Arizona contains provisions without precedent in any constitution ever submitted to Congress for approval by an applicant for admission to statehood. While declaring generally that the powers of the government shall be divided into three separate departments, the legislative, the executive and the judicial, and vesting the legislative authority in a legislature consisting of a senate and house of representatives, provision is made for the exercise of legislative power by small percentages of the qualified electors. Under the power to initiate legislation, ten per cent. of the qualified electors are authorized to propose any measure, and fifteen per cent. to propose any amendment to the constitution. Under the referendum power, five per cent. of the qualified electors may order the submission to the people at the polls of any measure, or of any item, section or part of any measure enacted by the legislature, except public health laws, etc.; and no act passed by the legislature shall be- 
come operative for ninety days after the close of its session, in order to allow opportunity for referendum petitions to be filed. Any measure referred to a vote of the qualified electors under the initiative or referendum shall become a law when approved by a simple majority of the votes cast thereon; and the veto power of the governor shall not extend to initiative or referendum measures approved by a majority of the qualified voters. The total number of all votes cast for all candidates for governor at the last preceding general election is made the basis on which the number of qualified electors required to sign the petition shall be computed. These rights of initiative and referendum are also reserved to the qualified electors of every incorporated city, town and county, as to all local, city, town or county matters on which such incorporated cities, towns, or counties shall be empowered by general laws to legislate. Under the power of the initiative, fifteen per cent. of the qualified electors may propose measures on such matters, and ten per cent. may propose the referendum on legislation enacted by or within such city, town, or county. If two or more conflicting measures or amendments to the constitution shall be approved by the people at the same election, the measure or amendment receiving the highest number of votes shall prevail in all particulars as to which there is conflict.

It will be observed that there is no requirement respecting the minimum number of votes which must be cast in order that an act of the legislature may be overruled, or a law directly enacted upon the initiative, or the constitution amended in any particular. All that is required is that the measure shall be proposed or the machinery set in motion by the above-mentioned small percentages of the qualified electors who voted for governor at the previous election, and then if a majority of the votes cast at the popular election are in favor of the proposed action or measure, it becomes effective, no matter how small a proportion of the total electorate of the State may be the vote, and without the slightest segard to its territorial distribution. Thus, if we should assume that the total of the vote cast for all candidates for governor at the last preceding election was that cast upon the proposition to adopt this proposed constitution, viz., 16,009 , then the constitution could be amended on the proposal of fifteen per cent. of that number, or 2,402 votes-that is less than one and two-tenths per cent. of the whole population, or about five and one-fourth 
per cent. of the whole body of qualified electors of the State, and carried by a majority of the 16,009 votes cast, that is, by 8,005 votes-or, indeed, for that matter, by any smaller number which might constitute a majority of the votes cast on the proposition to amend.

"The end of the institution, maintenance and administration of government," runs the preamble to the Constitution of Massachusetts, "is to secure the existence of the body-politic, to protect it, and to furnish the individuals who compose it with the power of enjoying, in safety and tranquillity, their natural rights and the blessings of life $* * *$. It is the duty of the people, therefore, in framing a constitution of government, to provide for an equitable mode of making laws, as well as for an impartial interpretation and a faithful execution of them; that every man may, at all times, find his security in them." 33

The uncertain sands of shifting popular inclination, upon which the security of life, liberty and property would depend under the Constitution of Arizona, are far remote from the conceptions of the framers of either the Massachusetts Constitution of I780 or the Constitution of the Lnited States.

But this is not all. Every public officer in the State of Arizona holding a public office, either by election or appointment; whether it be executive, legislative or judicial, is made subject to recall by qualified electors for the district for which he is elected to such office, which district may include the whole State. Electors to the number of ti'enty-fiz'e per cent. of the vote cast at the last preceding general election for all of the candidates for the office hel dby such officer may, by petition, demand his recall. This petition must contain a general statement in not more than two hundred words of the grounds of such demand, and unless the officer against whom it is directed shall offer his resignation within five days after it is filed, a special election must be ordered. to be held not less than twenty nor more than thirty days after such order, to determine whether he shall be recalled. On the ballots at said election shall be printed the reasons as set forth in the petition for demanding his recall, and in not more than two hundred words, the officer's justification of his course in office. Unless he otherwise request, in writing, his name shall be placed as a candidate on the official ballot without nomination. Other candidates for the office may be nominated to be voted for at

${ }^{33}$ Poore's Charters and Constitutions, p. 956. 
such election, and the candidate who shall receive the highest number of the votes cast shall be declared to be elected for the remainder of the term; and thereupon, if the incumbent does not receive the highest number of votes cast, he shall be deemed to be removed from office, upon qualification of his successor. Such recall petition may be circulated against any officer after he has held his office for a period of six months, and against a member of the legislature at any time after five days from the beginning. of the first session after his election.

"After one recall petition and election no further recall petition shall be filed against the same officer during the term for which he was elected, unless petitioners signing such petition shall first pay into the public treasury which has paid such election expenses all expenses of the preceding election."

Subject only to this provision, any number of recall petitions may be directed at the same official until his ejection shall have been secured.

Provision is also made for amending the constitution by a vote of a majority of the members elected to each of the two houses of the legislature and submission to popular rote. No convention may be called by the legislature to propose amendments to the constitution, or a new constitution, unless the law providing for such convention shall first be approved by the people on a referendum vote at a regular or special election; and any amendments, alterations, revisions, or new constitution, proposed by such convention, shall be submitted to the electors at a general or special election and be approved by the majority of the electors voting thereon before the same shall become effective.

The advocates of the scheme of so-called popular government embodied in the Arizona constitution have vigorously opposed the approval of that of New Mexico as reactionary, and have as strenuously asserted the republican character of the plan proposed for Arizona. It is an interesting paradox that the whole tendency of modifications in the established forms of republican government advocated as accomplishing a greater popular participation in government is to confer power upon a small minority of the people to control not only the making of laws, but of constitutions.

The postulate of American political faith is that governments derive their just powers from the consent of the governed. Taken in the literal, etymological sense of the term, no govern- 
ment has ever existed-certainly not on this continent-which was framed with the active conscious agreement of all those who were to be subject to it; while, of course, all government has rested, and must necessarily rest upon the more or less passive acquiescence or assent of those governed.

The Masachusetts constitution of 1780 recites that:-

"The people of this commonwealth have the sole and exclusive right of governing themselves as a free, sovereign, and independent State," and that "the people alone have an incontestable, unalienable and indefeasible right to institute government, and to reform, alter, or totally change the same when their protection, safety, prosperity, and happiness require it." ${ }^{34}$

Yet the right under that constitution to choose representatives to the general assembly is limited to male persons "being twentyone years of age, and resident in any particular town in this commonwealth, for the space of one year next preceding, having a freehold estate within the same town, of the annual income of three pounds, or any estate of the value of sixty pounds."

The right of suffrage, it was held by the Supreme Court of the United States in Minor v. Happersett, ${ }^{35}$ is not a necessary incident to citizenship of the United States, and whether women shall be allowed to vote or no is a matter left entirely to the discretion of the State governments. In his opinion in that case, Chief Justice Waite points out that when the Federal Constitution was adopted, in no State were all the citizens permitted to vote, and he summarizes ${ }^{36}$ the various qualifications required in the different States as a condition to participation in elections. In no instance were women, married or single, given the right of suffrage. They were expressly excluded from suffrage in nearly all the States by the express provision of their constitution and laws. "In all," to use the language of the Chief Justice, "the people participated to some extent, through their representatives elected in the manner specifically provided."

The fact is, that even government by folkmoot or town meeting, was government by a certain number of the community, less than all, assuming to represent those who from motives of policy or tradition were excluded from participation by those who were

34 Poore's Charters and Constitutions, 958.

${ }^{3 \pi} 21$ Wall., I63.

36 See p. I72 et seq. 
strong enough to exclude them. So at an early date, in this country, the unwieldy nature of government by a large assembly of the adult male population, possessing agreed qualifications to entitle them to participate, brought about the plan of choosing a practicable number of delegates to meet and enact "such laws and ordinances as shall be judged to be good and wholesome for the whole."

This plan of the qualified electorate choosing representatives to make laws, naturally led to the formulation of charters or constitutions prescribing the rules and limitations within which such representatives should act, and in nearly all of these constitutions, certain inalienable rights are enumerated which must be preserved and which law makers must not trench upon or impair.

In the framing of the early State constitutions, as indeed in most of the later ones, care was observed to secure their approval by as large a number of the adult male population as was practicable. In general, the delegates were chosen by votes at a special election, and after their work was completed it was submitted to the qualified electors for their assent. The sense of obligation felt by delegates engaged in the high duty of framing the fundamental law is expressed in the address issued by $\mathrm{Mr}$. Bowdoin, the President of the Massachusetts Constitutional Convention of 1779 , enjoining upon the members of the Convention the exertion of their best abilities in framing "a new and a good Constitution of Government," and stating that "as the framing it, and its acceptance, when framed, must greatly depend on the collective wisdom of the Convention being had, in the final determination on every part of it, but which cannot be had without a general and constant attendance," he was directed by vote of the Convention "to enjoin upon the members, from its necessity and importance, A CONSTANT AND GENERAL ATTENDANCE accordingly." 3 i

It is not to be wondered that a constitution so framed should have remained to this day with but little amendment as the living fundamental law of the great Bay State.

In order to secure the widest possible popular concurrence in the choice of delegates to the Pennsylvania convention of 1777 , commissioners were appointed by the assembly "to go to the house or place of residence of each and every freeman entitled

${ }^{37}$ Lobingier, pp. I72-3. 
to vote for members of General Assembly within their respective townships, boroughs, wards or districts, or to take some other opportunity of meeting with them," to secure from every freeman, in writing; his vote or answer to the proposition, which should be put in a box provided for the purpose and returned to the general assembly. ${ }^{38}$

Unfortunately, the British invasion suspended the carrying out of this rather novel but highly commendable plan; but subsequently, by a more orthodox method, delegates were chosen by popular election who prepared the constitution which remained the fundamental law of Pennsylvania until 1838 .

Framed, therefore, by delegates especially chosen for the purpose, with the design of establishing a permanent and stable form of government, until a recent date the constitutions of all the States avoided detail, and laid down merely the general outlines of the frame of government within whose limits details were to be supplied from time to time by the legislature constituted according to its terms; and provisions were embodied with respect to amendments calculated to secure deliberate matured action, and especially to require the active concurrence in the changes proposed of an actual majority of the qualified electors.

Jefferson's proposed constitution for Virginia contained a provision that none of the fundamental laws and principles of government should be repealed or altered but by the personal consent of the people at meetings held in the respective counties, the people of two-thirds of the counties to give their suffrage for any particular alteration. ${ }^{39}$

This Jeffersonian theory of making the alteration of the constitution dependent not only upon a certain percentage of the vote cast, but upon the consent of a specified percentage of the geographical subdivisions of the State, as we have seen, is embodied in the proposed constitution of New Mexico. The first constitution of Georgia required the consent of a majority of the counties to any amendment. The Massachusetts constitution of I780 was to take effect upon a vote of two-thirds of the free whites voting upon it.

In general, the State constitutions prior to the very recent ones, required the vote of at least a majority, sometimes of twothirds of each of the houses of the legislature in favor of a

38 Lobingier, p. $15 \mathrm{~T}$.

39 Lobingier, p. If6. 
proposed amendment, sometimes at two successive sessions of the legislature, and then submission thereof to popular vote and its adoption by at least a majority of all votes cast with respect to the proposition, sometimes by a certain proportion of the entire qualified electorate. There would seem to be little use in choosing a convention of delegates to frame a constitution, who, after careful consideration and patient work, submit the same to popular vote, if, after adoption, no stability or degree of permanency is secured, but the results may be changed as readily, and perhaps more readily, than an ordinary act of the legislature. The system which was the evolution of American growth and institutions; the distinctively American plan of government under fundamental law framed with a view to its continuance unless changed with equal solemnity, is absolutely at variance with the new scheme of government by initiative, referendum and recall embodied in the constitutions of Oklahoma and Arizona; a scheme which, as MIr. Bryce has pointed out in "The American Commonwealth," 40 first made its appearance in modern Europe as a provision of the French constitution framed by the national convention in I793, and which has peculiarly flourished as a feature of the government of Switzerland.1 The real question presented is whether or not all the people shall be governed by representatives chosen for the purpose in an orderly, regular way, acting in accordance with a well matured fundamental law, adopted by the active concurrence of at least a majority of the adult male population; or by self-constituted representatives acting without direct responsibility under the haphazard system of initiative or referendum at the instance of a small minority of the electorate.

By the constitution of Ollahoma, suffrage is restricted to male citizens, except at school district elections or meetings; and by a recent constitutional amendment ${ }^{22}$ adopted in deliberate disregard of its solemn compact with the United States, all negroes have been, in effect, disfranchised; so that out of a total population of $1,414,042$ (according to the 1907 census), not exceeding 334,035 white males of the age of twenty-one years and upwards, are permitted to vote. Fifteen per cent. of this number, or

4" Vol. I, p. 465.

42 Dodd, "Modern Constitutions," p. 258 .

42 Amendment as section $4 \mathrm{~A}$ of Article 3 of Constitution Session Laws IgIo, p. 285. See also Ata'atcr a. Hassett, in I Pacific Rep., Siz. 
50,105 electors, may set in motion a proposition to amend the fundamental law, which will become effective if approved by a majority of those voting on the proposition, no matter how small a percentage of the whole population or of the qualified voting population that number may be.

The proposed constitution of Arizona also restricts the suffrage to male citizens of the United States of the age of twentyone years or over, who shall have resided in the State one year immediately preceding the election (Art. VIT, sec. 2), so that, out of a total population of 204,354, according to the last census, not exceeding 45,323 white males of twenty-one years and upwards are permitted to vote. Fifteen per cent. of this number, or 6,799 electors, may set in motion a proposition to amend the fundamental law, which will become operative if approved by a majority of those voting on the proposition-no matter how small that number might be.

In other words, under the scheme of government proposed in the constitution of Arizona, as in that of Oklahoma, all the fundamental rights of person and property which are not specifically guaranteed and secured by the Constitution of the United States, but which are left as the subjects of State concern-such as the right of religious toleration-are at the mercy of a small minority of the population. Of course, it may be said that eternal vigilance is the price of liberty, and that citizens who fail to assert their rights and to be vigilant in their protection, cannot complain if they find them undermined, impaired or destroyed. Professor Lobingier argues that statutes which require the concurrence of a majority of the electors in constitutional changes should be construed so as to require only the consent of a majority of those voting on a proposition-not of all the electors. He says:

"From the standpoint of public policy, however, it would seem that those decisions are. soundest which construe the language wherever possible as requiring only a majority of those actually participating in the vote on the submitted proposition. To declare a constitution or amendment rejected by reason merely of the indifference of those who, while in attendance at the polls, are so unmindful of the privilege of popular ratification as to neglect its exercise when opportunity offers, is certainly to impair its benefits and often to impair its employment when not needed." (p. 330.) 
But if the constitution is the expression of the will of the whole people, is it not rather to be presumed that, if a majority of the people really feel that a change in the fundamental law is necessary, they will affirmatively so express themselves. Let it be necessary to secure the vote of an actual majority of the qualified voters to a proposed constitutional amendment, and, if the change is really desirable in the interest of all the people, that fact will be made manifest, and the vote will be secured. The anxiety of the advocates of the referendum, initiative and recall to have them operative at the instance of small minorities of a restricted electorate, furnishes abundant evidence that it is they-not those who oppose these innovations-who do not trust "the people" or even a majority of the people; but that, under the guise of serving the people, they are seeking to lay hands on the power of the people and to arrogate to themselves the popular tribunate.

Bearing in mind the practical worlkings of everyday life in a busy, prosperous, commercial community, it is apparent that a large number of the community, and that the most productive portion of the community, do not, and cannot, give constant attention to the affairs of government. Under a scheme of government such as that proposed in the Arizona constitution, a small minority of the qualified electors organized to accomplish any particular purpose can mould the laws, or even the constitution, to accomplish their purposes before the great majority of the electors are aware of what is going on. The propositions submitted to the electors under the scheme of initiative and referendum are fixed and put before the voters without the advantage of the examination, discussion and debate which have been, throughout the whole history of English speaking peoples, the crucible in which legislative projects have been tried out before enactment into law. It is an abuse of language to call such a scheme of government "popular." It is an attempt to create a government of all the people, by a minority of the people, for a small minority of the people. To adopt it, would be to substitute for the institutions which are the growth and evolution of centuries of American experience, the devices of French revolution and Swişs socialism.

George IV. Wickersham. 